EVS26

Los Angeles, California, May 6-9, 2012

\title{
Governing and Innovation: the Transition to E-Mobility - A Dutch Perspective
}

\author{
Martijn Van der Steen ${ }^{1}$, Peter Van Deventer ${ }^{2}$, Hans De Bruijn ${ }^{3}$, Mark Van Twist ${ }^{4}$, \\ Ernst Ten Heuvelhof ${ }^{5}$, Kingsley E. Haynes ${ }^{6}$, Zhenhua Chen ${ }^{7}$ \\ ${ }^{I}$ (corresponding author) Netherlands School of Public Administration, Lange Voorhout 17 \\ 2514 EB Den Haag, steen@nsob.nl \\ ${ }^{2}$ Province Noord-Holland, deventera@noord-holland.nl \\ ${ }^{3}$ Delft University of Technology, 2628 EB Delft Netherlands, j.a.debruijn@tudelft.nl \\ ${ }^{4}$ Erasmus University Rotterdam, Burgemeester Oudlaan 50, 3000 DR Rotterdam 3062PA, Netherlands, \\ vantwist@fsw.eur.nl \\ ${ }^{5}$ Delft University of Technology, 2628 EB Delft Netherlands, e.f.tenheuvelhof@tudelft.nl \\ ${ }^{6}$ George Mason University, 3351 Fairfax Dr. Arlington, VA 22201, United States, khaynes@gmu.edu \\ ${ }^{7}$ George Mason University, 3351 Fairfax Dr. Arlington, VA 22201, United States, zchen7@gmu.edu
}

\begin{abstract}
This is an essay approach to develop a discussion about the role government can play in stimulating electric vehicle (EV) diffusion, adoption and deployment in support of larger societal goals such as sustainability and urban livability. This reviews governance strategy in support of electric vehicle innovation in a way that integrate many societal actors, including the market to move forward a project with many spillover benefits. It does this by reference to examples and projects in the Netherlands, the EU and the U.S. that articulate these strategies. This is a Dutch perspective because it is written in that context but it has examples and viewpoints that should have a wider appeal.
\end{abstract}

Keywords: EV (electric vehicle), mobility, government, innovation, Netherlands

\section{Introduction}

It is 1996 and the first electric vehicles (EVs) are starting to appear on Californian roads. The State of California supported the introduction with capital investment and political engagement and the underlying infrastructure was being developed in public places, commercial areas (e.g. the Vacaville shopping center) and in homes. In only a few years after the launch, the number of EV reached a peak of some 10,000. Momentum was building and sales were booming. Suddenly, it all stopped. Vested interests (oil companies) exert their influence and car companies like GM, Toyota, and Ford stop production. Lease programs were cancelled. EVs were recalled. State governmental commitments faded and attempts to realize sustainable policies faded. The economic promises of electric driving were no match to reality. As rapidly as it arrived, the EV was killed, and it vanished without a trace. If electric driving is the solution, what then is the problem? Is it the urge for clean mobility, the quest for alternative energy sources, public demand for oil independence, or is it about a new economic perspective? And, if electric driving is the solution, then why is it not happening, at least not by itself? Why did the introduction of electric cars in California fail in the late 1990s? And, crucial to the deliberation of governance options: what is the role of government? What can governments do to 
accelerate mass introduction, strengthen it, and make it sustainable?

All over the world companies, universities, governments, and private individuals are working to introduce electric driving. All are taking smaller or larger steps that at one time or another will contribute to a relatively massive transition. Electric vehicles (EVs) are still a rare sight on the road but preparations are underway for change. Revenge of the electric car (2011) is a new documentary on our near future and the possibilities we can expect. It is the counterpart to Who killed the electric car (2006), a critical documentary on the failed launch of electric cars in California. It is a meaningful symbol of the turning of the tide for electric vehicles. It is happening, and fast. But is it fast enough? And is the growth steep enough to deliver the necessary volumes? And is the momentum sustainable?

Long preparation time is understandable. There is more involved to introducing electric driving than just launching a new type of car. The question about electric driving is not just about doing it. It entails a transition to new thinking about mobility.

Electric driving means a transition to a new system, with new applications, and radical change to the underlying infrastructure. New vehicles are one aspect. The introduction and integration of public charging stations is a second aspect. A third aspect is the development of a smart grid; an electricity network that not only supplies energy to consumers but also allows consumers to give back to the grid. Customers will become 'prosumers', alternating between producers and consumers. To energy companies the opposite applies. They will no longer solely supply clients but will have to start negotiating the supply with their clients.

All this means a fundamental change in the existing order and balance of authority. Power companies will not only supply energy to customers, they will have to negotiate with customers on their energy resources. They will not only deliver energy they generate, but temporarily store and use the energy generated by what was previously known as customers and connections.

The introduction of EVs is about a new technology, and about breaking through the existing balance of power and the emergence of a new balance. A change in mobility is not just random policy, but has everything to do with changing deeply rooted cultural patterns.
There is a special relationship between consumers and their cars. Any attempt to intervene in this special relationship at a level other than silent replacement of one system by the next will be difficult to achieve.

Electric driving is an emerging domain. New opportunities are hovering on the horizon, but what they are and what they make possible is still unclear. Everybody is trying to act strategically, but the direction of that strategy is unclear, as unclear as the context in which it will have to develop. Therefore, the introduction of electric cars is a complex and widespread issue that crosses boundaries of both time and domains. This complexity comes back to the question: what can we do to sustain progress in the long term?

\subsection{Research Approach and Guideline}

This is not a traditional research paper but rather a discussion paper based on a wide spectrum of research sourced from the references. This essay addresses the various circumstances and system properties that constitute the dilemmas surrounding the introduction of e-vehicles. First, we describe the dilemmas and then elaborate on possible strategies for dealing with them, not only for governments but also for other organizations.

This essay includes a study of relevant literature blended with data collected at conferences and meetings in the Netherlands and the US. We have spoken with a large number of parties and stakeholders active in this field. We went on three study tours to the US to collect information on the introduction of EVs. We shared knowledge with many contacts and stakeholders engaged in the process.

\section{Introducing the EV: Clear and Complex}

\subsection{Motivation}

Why should governments strive to replace the classic internal combustion engine with electric driving? Motives differ, depending on the specific application and the local context.

\subsubsection{Sustainable, clean mobility}

A primary, often used argument is the clean and sustainable character of electric driving. This argument has two levels. First, e-vehicle $\mathrm{CO} 2$ emission is close to zero. In highly urban areas, EVs would have a great impact on local air quality. With clean vehicles, the central cities will 
not need to be made car-free. The second benefit involves improvement on the system level. Electric mobility creates a drastic reduction in pollution, but only under certain circumstances. If energy for the electric vehicle is produced more cleanly than it is produced for the classic oil-fueled combustion engine, everyone and the environment will profit. If power is generated in 'dirty' coal plants, then the gain on the whole regardless of the tangible benefits for local air quality - would be limited, even if emissions are cut down to less than half of those made by an efficient combustion engine. If energy comes from nuclear power plants, there would be no emissions, but we would get a serious waste problem instead.

The solution may be to generate power from solar, wind or water resources. Natural resources make it possible to drive sustainably and virtually free of pollution and emissions. Potentially it means that governments can move forward in achieving public goals of sustainability and pollution reduction. The same is true for car batteries; if they can be recycled, it will increase the sustainability of clean electric vehicles overall. With a sustainable solution, the world can move forward to a cleaner future.

\subsubsection{Reduction of oil dependence}

The second argument in favor of electric vehicles for Western countries is a step towards reducing dependence on foreign oil. Current dependence on foreign oil means large capital investments in countries and regimes with which Western economies may find themselves at odds. It creates dependency in the sense of political vulnerability to oil pricing and boycotts. The capital flows from the West to the oil-producing countries and flows back to the West as investments in companies and property. This is how capital - driven largely by oil dependence is slowly creating a shift in the structural balance in global relations. Thus, the West depends not only on foreign oil; it is also dependent in a much broader and deeper sense.

Western economies and countries can only break free from their oil dependence when their engines are replaced with new technology. The electric car is one of the most practical options available to achieve independence.

\subsubsection{International competitiveness}

A third argument for electric vehicles is found in the economic advantages that national economies could achieve. The idea is that in the long run, internal combustion technology will disappear. Eventually, oil will run out or be priced out. The expectation is that one day this technique will be replaced by something else, out of several possible alternatives. Electric driving is one option, with hydrogen-fuel cell driving the main competitor. If this is the long term trend, it would be economically rewarding for national economies to hold advanced positions in the EV field. This substantial field includes: the development of industry that focuses on production of cars, batteries or components; innovative industry that focuses on improving the processes and associated construction; service industry that provides new opportunities around the new technology; and finally, ICT industry that sees new opportunities for Applets, smart grid technology, nanotechnology, and related semiconductor technology. From the assumption that new technology is coming, there are a range of arguments for governments to be involved at an early stage.

\subsubsection{Public pressure}

A fourth argument is that the public, or certain parts of it, want electric driving. There is pressure on governments to get busy. Parts of the public are demanding government step forward to respond to developments. They believe it is important. They can see what other countries are doing, and compare these efforts with that of their own government. The idea is that government must take relatively big strides on sustainability in order to stay in step with other parts of the world. For example, the large amount of public funding Germany has invested in solar energy puts pressure on the Dutch government. 'Why can the neighbors do it and not us?' Dutch citizens are asking. 'What are we missing out on?' And, 'We should be up there, with the leaders.' Groups in society are exerting significant pressure on the Dutch government to do something about electric cars. It is not only economic rationality, but a broad sense of public urgency that steps can and should be made to attain sustainable mobility. This urgency translates into political pressure for governments to act.

\subsection{Policy making takes off}

The arguments for taking steps toward electric cars are powerful. Unsurprisingly, many countries have already undertaken important policy moves. At various levels in several countries much is being done to introduce electric vehicles. In the Netherlands, for instance, the Task Force has 60 
million euros at its disposal for the period 20102011. The government already provides support for electric vehicles through tax credits. Provincial governments are also trying to launch customers by purchasing vehicles on a limited scale and by building infrastructure to support their use. Initial infrastructure is being built in the cities of Amsterdam and Rotterdam. The provinces of Noord- Brabant and Noord-Holland are holding exploratory talks about regional cooperation with municipalities and transport authorities on EV use. The policy theory is that developments should be market-led with (local) government stimulus. The goal is to have one million electric vehicles driving on Dutch roads in 2025. Furthermore, the joint network operators have established, Stichtinge-Laad, (e-Laad Foundation) with the aim of ensuring a reliable electricity network for the transition to electric cars on a large scale. The e-Laad goal is to have $10,000 \mathrm{EV}$ chargers in place by 2012 , available to users for an all-in tariff of 100 euros a year, including electricity generated from sustainable sources.

The EU recently formulated a strategy for electric vehicles, setting aside an innovation budget of some 5 billion euros. The 'Green Cars Initiative' aims to support the automotive industry during economic downturns and make the transition to new forms of sustainable mobility. Besides this European-level initiative, EU member states are planning individual initiatives, with the Netherlands, Denmark, Ireland, and Portugal leading the way.

In the US, the federal government has made large sums available through a stimulus package to support EV innovation and research, including research into battery and charging technologies.

It is important to note that most US policymaking is not federal, but done at the local and state level. US cities run their own agenda to establish governmental fleets of electric cars or charging stations. States like California have led the way over the past four decades with ground-breaking policies on air quality, incentive, programs, and infrastructure. California expects to have two million EVs by 2020.Assembly Bill 32 (ab32) was offered with 100 million dollars of support annually through the California Energy Commission (CEC).

A strong base of cooperation between committees, NGOs, companies, utilities, and universities makes the California approach very interesting. Various initiatives between these organizations have resulted in the development of so-called $\boldsymbol{E} \boldsymbol{V}$ corridors. Other interesting US initiatives can be found in states like Oregon, Washington, and Maryland (Baltimore EV Initiative). States like Ohio and Tennessee are investing in electric driving components as industrial reform is needed due to high unemployment rates $(>10 \%)$. The state of Tennessee, in contrast, has made large subsidies available for the Nissan Leaf production site. In California the Nummi plant at Fremont with a potential production of 600,000 cars per year did not close when GM and Toyota moved away but stayed open for the production of the Tesla Model SEV, starting with a target of 20,000 cars a year.

\subsection{Uncertainty, Fear and Lack of Clarity}

If we have four economically and politically sound arguments for doing something, and if ambitions and policy have been translated into many concrete goals and programs with associated budgets, then why is it not "all systems go"? The answer is of the same order as the argumentation in favor: several powerful uncertainties hinder the large scale introduction of electric vehicles.

\subsubsection{Technical uncertainty}

The first cluster of concerns focuses on technology. What is the battery quality like? How far can I drive on a full battery? How secure is the technology? How long does recharging take? Technical limitations are still unclear to the public. These uncertainties are crucial to the use of the technology and its release. This is not purely about technology as such, but more about the perception of its potentials. Range anxiety (how far can I drive?) may deter many potential users and suppliers. The car runs on batteries which after a certain distance require recharging. The vast majority of trips people take every year are well within the range. Yet many people are afraid of the technology because each year they might want to take a few trips beyond that range. People wonder, can I use the e-car on vacation? Thus an objective, technical limitation gains subjective meaning, which in this case is somewhat blown out of proportion so that lots of attention gets drawn onto the limitations of battery technology. With this anxiety in mind, an electric car would seem to be inferior in comparison to conventional fueled cars.

\subsubsection{Creative destruction}

A second discussion focuses on the social impact of electric vehicles. This is mainly about 
suspicions of creative destruction. Electric driving makes something new possible, but at the expense of something existing. For example, in areas where there is great dependency on the traditional automotive industry, introducing electric vehicles may create unemployment. As with any innovation, it is uncertain how and where the revenues and costs of the alternative will appear. This causes people to worry.

\subsubsection{Support System Dependence}

A large area of misgiving about electric cars surrounds the entire infrastructure of the electric car. It covers many aspects, such as the network of charging stations that must be built, the power needed for the electricity supply, the required capacity to handle varying peaks and the charging speed. Similarly, what is the necessary density of charging points. How to build charging points in homes and what is required in renovation and rerouting of cables and pipelines. This also brings up questions of safety. Add to this the uncertainties about the support system, the public may get the idea that the system can only be credible and economically viable when all conditions are met.

\subsubsection{Truly renewable energy}

How clean will the produced energy be? Is it truly sustainable? Can we find a solution for the problem of proper distribution of electricity through the grid? A massive shift to clean energy could mean that electric driving would cause virtually no emissions, but if energy is generated in coal plants, there would be a less positive effect. There are also questions related to battery lifespan and the possibility of reusing $\mathrm{EV}$ batteries.

Can we develop markets for used batteries or will batteries have to disappear in the waste cycle? If we are unable to resolve the issue of battery recycling then the environmental problem merely shifts, from emission to storage. Even if energy is'clean', old batteries may cause new and massive environmental problems.

\subsubsection{Economic conditions}

Price is another uncertainty. Can electric cars become competitive with existing methods of mobility? The cost of the vehicles is still uncertain. Fully electric cars are on the market, but they are still relatively expensive, especially due to the cost of batteries. Tax incentives and subsidies can compensate, but the question is how long such arrangements can last.

The price of the infrastructure is unclear and literally unpredictable. It is difficult to anticipate how prices will develop, because this is heavily dependent on production volume and that has not been established. Technology has yet to crystallize, and as many different systems are in use, it is unclear how the price will develop in the next few years.

\subsubsection{Uncertain markets and firmly established parties}

The market is another uncertainty. The established automotive industry has several brands entering the market, including Japanese, European, and US manufacturers including Toyota, Nissan/Renault, BMW, VW, Peugeot and GM. New players are producing cars, or specialize in vital components such as batteries and charging stations. How will the market develop? Traditional players are still making money on conventional cars. Some of these players appear to be entering the EV market reluctantly. They are joining in to not miss out. It is unclear how strong these commitments are and what the top priorities are when financial resources become scarce. Players are still waiting to hear the real preferences of consumers. It is unclear if consumers are ready for EVs. In today's car industry, how will companies market electric driving to interest consumers?

\subsubsection{Governmental Intentions}

Various countries are showing political support for transport innovations and experiments, but how long will this continue? Political tides change. In the US it is almost inconceivable that a Republican president would continue current Democratic policy. For instance, the State of California witnessed a political battle in November 2010: Proposal 23, supported by two Texan oil companies, aimed to suspend ab32 (see above), until unemployment had dropped below 5.5 percent for a full year. Although Proposal 23 was rejected by Californian voters, it demonstrated the 'anti-movement', which can become an important factor to consider. This applies to other countries as well. If sustainability slipped to a lower priority, the anticipated millions of euros to promote electric cars may become an illusion. Under current economic circumstances, it is difficult for governments to maintain prolonged commitments. In addition, it is unclear how much political capital governments are willing to spend on 
keeping this issue on the agenda, let alone intensifying attention for it.

\subsection{Uncertainty as Strength}

These uncertainties may have an unintended negative connotation and be regarded as threats to the introduction of electric cars. Uncertainty can also be seen as a positive. Things we do not know about electric cars now could turn out to be decisive in future. The introduction of the electric car is an innovation that brings two systems together: electricity and transport. The innovation logic straddles the borders of both systems so there is lots of potential for new innovation. This usually leads to unforeseen creativity and invention. The potential is great, but so is the uncertainty. We can say little about it now - it's uncertain - but we do know that serendipity can be a significant aspect of innovations and usually occurs. These unforeseen innovations can turn out to be the most crucial.

\subsection{Interim Conclusion}

There is a strong call for rapid and massive deployment of electric vehicles. In many aspects it is a cleaner, cheaper, smarter and an advanced solution for mobility. But it is also a controversial technology. The benefits are unclear, as are the possibilities of competing technologies to further improve and respond to current concerns.

There is still much to do before electric mobility can take place on a sufficiently large scale. Big investments in the power grid must take place, but which ones exactly? The answer is anything but obvious. There is a correlation between electric vehicles and a smart grid. The electric car can be the "killer app" for the introduction of a smart electricity grid, but that in itself would not necessarily mean anything to the pace of introduction of electric cars. But without a smart grid, the electric car is not as attractive as it could be. The prospect that one day there will be a smart grid, and electric cars will gain more than usual benefit from it is no argument for consumers to purchase an e-vehicle today. There are many signs that a mass introduction of electric driving will benefit society, but at the same time there are forces and conditions that make it just as unlikely.

\section{Governance Complexity}

Doubts and uncertainties, and their distribution across the different actors in the electric driving arena have led to complexities that we will catch and describe as games. In each play, the game construction is the same: actors face both advantages and disadvantages but, in the current situation, the disadvantages always come first. They appear earlier than the advantages and are compelling, at least in the short term. We demonstrate the dynamics of the various games and present possible solutions that may reverse the favour for waiting into a bonus for an early move strategy. Below, we translate those decisions into smart strategies. Fundamental interventions could resolve current tensions.

\subsection{A 'wicked policy' problem}

The introduction of electric cars is a classic example of what is usually referred to as a 'wicked policy' problem. And not one, but several. First there is the combination of uncertain, controversial knowledge and values.

There are various theories about the usefulness of electric driving, including best solutions and alternate options. There are compelling theories that argue that electric vehicles are not a realistic or cost-effective option. Although this analysis deals with both supporting and opposing theories, it also deals with the different camps of supporters and opponents. At the present level of knowledge, it is not easy to find stability.

For wicked policy problems, there is no agreement at the level of underlying values. It is complicated in that proponents of electric cars often fall back on conflicting values. Geopolitical considerations about oil dependency and sustainability do not need to clash head on, but often these good 'eggs' are not even 'in one basket' among politicians. The usefulness and necessity of electric cars is not unequivocal for everyone; the value of sustainability is not shared by all, especially when placed head-to-head against other values. Because it concerns the deployment of scarce resources, such as tax revenue, this dilemma is always in play.

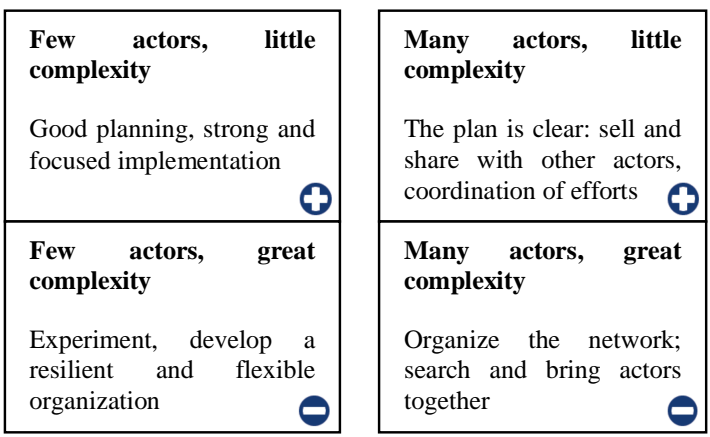

Figure 1: The Arena of E-Mobility 


\subsection{Stakeholders}

Electric driving is not only a wicked policy problem, it must also be developed in an arena that requires many actors and actions in order to make progress. The wickedness causes all kinds of collective action problems. If Amsterdam promotes electric vehicles with infrastructure, grants and licenses, but forgets to make arrangements with the region, its citizens might be able to drive on the beltway, but they will never get into Utrecht, Alkmaar, or Almere. Amsterdam has limited capability, because success lies in the hands of others.

If substantive complexity is limited and there are only a few players, implementation is relatively simple. If there are few players, but there is more substantive complexity, a longer and better process could provide the ultimate solution and strategy. Simple implementation could follow, at least through a manageable number of actors. However, when the arena has many different actors, each with different levels of commitment and involvement, and often with the ability to control and add on to the process, possible strategies change. Control is focused more on moving and bringing together interests rather than on formulating what is needed and rolling out the plans.

The complexity and multiplicity of actors is not necessarily restricted to the commercial players in the market. It also includes governmental authorities. In situations with many different actors and issues of limited complexity, it is all about intelligent networking and proper project management. When complexity is substantive, and the policy arena is cluttered by many and diverse players, it requires strategic game play by various actors to combine their knowledge and cooperatively create viable and sustainable solutions. These actors must also be committed to continuing the process of implementation. Instead of project management, this is good process management. Serial brainstorming and implementation run more or less in parallel and at the same time, involve many actors at all stages of the process.

The provincial government of Noord-Holland is currently discussing the first steps in creating a 'circle corridor' with strategically located fastcharging stations. The construction of the stations is not the most complex of tasks, but connecting the charging stations to many other features, such as rail, park-and-ride bus services, and other public services is complex. The combination of features increases the value and potential of the charging stations, but it also increases complexity. It is not difficult to roll out such networks independently of other networks and infrastructures, but in relative isolation, their value is limited. The combination of many different functions and networks is what makes it hard: but it is also what makes it worthwhile.

\subsection{Commercial Actors: Wait, Move, Invest, or Copy?}

All actors who have to come up with the good inputs keep each other hostage in a game ruled by the timing of their efforts. This is particularly true for commercial actors. Electric driving involves initial large investments, while many benefits can only be reaped later on and will often profit actors who contributed little initially. As indicated earlier, actors may be uncertain about the best technology to invest in.

This is the dilemma: all potential solutions have advantages and disadvantages. Waiting and early movement are both promising strategies, but they also harbor risks. Whoever starts quickly could gain first mover advantage and shape market standards. Remember TomTom? First on the market in the EU/Netherlands at least, it has become almost the killer brand for mobile navigation. First movers can often count on extra government subsidies, which are larger in the earlier stages than later on in the process. On the down side the early mover may get trapped in his tracks. By investing heavily when the product was still under development, early actors may lose the ability to respond to what the market really wants.

The opposite of moving early is to wait and see. Who dares wait the longest before making investments? Given the circumstances, this is a very understandable strategy. Waiting long enough can ignore the traps of early leadership. Simply copying successful product strategies at no developmental cost or risk is obvious but wait too long and you run into the costs of catching up, particularly when the early mover is successful. More cautious parties will incur market recovery costs. The leaders may have put out patents, divide the market between them, and snap up the best talent in the business. Consumers develop certain images of the market. The risk of waiting is missing the right boarding moment. At this very time, all players in the electric driving market are facing the same dilemma.

In practice the distinction is obviously not binary. Many parties seek to cope with both sides of the dilemma, even if the cost of this dual strategy is high. They invest, but not at any price. They 
participate, but not all out. They bring new models onto the market, but prefer to supplement the existing market rather than start a transition. The paradox of this game is that the motion of the early starters automatically activates the waiting actors. Once the process swings into motion, the others follow. Yet arena dynamics suggest that starting up this process does need some help.

\begin{tabular}{|c|c|}
\hline $\begin{array}{l}\text { Early mover, set the } \\
\text { standards } \\
\text { First mover advantages }\end{array}$ & $\begin{array}{l}\text { Wait and see, pick the } \\
\text { fruits of investments } \\
\text { made by others } \\
\text { Copy cat advantages }\end{array}$ \\
\hline $\begin{array}{l}\text { Early mover, it takes } \\
\text { great effort to overcome } \\
\text { any bad choices } \\
\text { Entrapment, lock-in } \\
\text { effects }\end{array}$ & $\begin{array}{l}\text { Wait and see, miss out, } \\
\text { forced to purchase the } \\
\text { technique, risk failing to } \\
\text { attract talent } \\
\text { Cost of catching up, } \\
\text { lagging behind }\end{array}$ \\
\hline
\end{tabular}

Figure 2: Who Makes the Market?

\subsection{Supporting innovations: policy, planning, regulation, or just letting go?}

Policymakers face a similar dilemma in the game that shapes their strategic actions. They too must consider a number of actors and the processes in which they invest. They want to give supportive nudges but they are not clear on whom they should choose to nudge or by how much. The choice requires knowledge of who is or will become the best player on the market, but favoring some ahead of the rest may reduce the stimulus of innovation and entrepreneurship. Such support will not push the market constructively, it will only result in processes aimed at tapping subsidies. Do windmills turn because of the wind or do subsidies blow them? Do solar panels generate energy or do they burn subsidies? Support, especially in the current era, is a zero sum game. Funding for one initiative comes inevitably at the expense of resources for other initiatives. Financial space is limited, so the use of scarce resources and political capital is by definition risky.

Electric driving is an emergent issue and therefore, by definition, unclear. The broad contours may be well known, but the exact interpretation of the fine lines will only become clear gradually, over time. The ultimate question is whether policymakers can indeed predict the winners of a battle over a largely uncertain, still developing issue. The history of state support is crowded with sad examples. However, if the government wanted to leave enough room for variety and selection, and ignored choosing the ultimate winner as a starting point, this would postpone the final choice as long as possible. Then the choice of winner is not made by an external party (i.e. government), but arises in the market. The market selects, some actors and their techniques will grow stronger while others will disappear or be marginalized.

\begin{tabular}{|c|c|}
\hline $\begin{array}{l}\text { Picking winners } \\
\text { Early selection and } \\
\text { support; staying ahead of } \\
\text { the game }\end{array}$ & $\begin{array}{l}\text { Spreading chances and } \\
\text { risks } \\
\text { Maximum variety and } \\
\text { postponed selection; } \\
\text { following the market }\end{array}$ \\
\hline $\begin{array}{l}\text { Lock-in } \\
\text { Continuing support even } \\
\text { when you are on the } \\
\text { wrong track; protection } \\
\text { of investments, long term } \\
\text { commitment to losing } \\
\text { tcchnology }\end{array}$ & $\begin{array}{l}\text { Inefficient support } \\
\text { Inevitable investments in } \\
\text { losers and limited } \\
\text { investments in future } \\
\text { winners; problematic in } \\
\text { efficiency discourse }\end{array}$ \\
\hline
\end{tabular}

Figure 3: Supporting Innovation

Therefore, government strategy should be to ensure diversified funding, and couple that ideally with interventions that ensure the market stays as fair as possible, with a level playing field for all actors. Providing a maximum set of equal opportunities for a variety of options will bring out the best. Many of these investments should be amortized as sunk costs and the government should be prepared in advance for companies to perish if they do not appear to be a winner. This is a high price, both economically and politically.

\subsection{Costs: Distribute, Allocate, Divide}

Because the transition to electric driving is so radical, a crucial feature of the problem is the long time lag between the moment of investment and the generation of income. Investment in research and development and in new infrastructures must be done in the short term, but it will only get paid back in the long run. The costs and benefits are often also divided among several actors.

Sometimes distribution is relatively simple. The actor that invests is the one to get the first, most tangible benefits. Then the choice of whether to invest can be made through a simple business case. But more often investments and return on investments are further apart or scattered among various actors. An early investment may create immediate benefits to all actors (including those 
who wait), or it will create benefits only over a very long period, possibly after a few generations. That does not mean it's still a problem, but it can make assessment harder. If it is harder for actors to protect investments, uncertainty increases. And there is always a risk that other actors will run away with the benefits. Whoever invests first is sometimes forced to see other actors who have waited enjoying the benefits. That implies that waiting may be a productive strategy; don't be the first to build the infrastructure, but wait until it's there and then use it.

Actors who invest wish to protect their investments. They do this partly by investing early in the process and thus creating path dependency. But that is still a risky strategy, especially if the investments are as major as in the case of electric vehicles. Another option for protecting investment on such things as infrastructure is to keep your investment closed off to others, or make it accessible at great cost. Telecom providers earn money on 'roaming' whereby they require others to pay for using their network. Closing systems off or charging for access to protect investments can persuade actors to invest early, which may be good for the process, but it can also lead to the innovation process closing down. Open systems and standards are more innovative, but from the standpoint of investment protection it may be more profitable to keep the system as closed as possible.

\begin{tabular}{|c|}
\hline $\begin{array}{l}\text { Short timelag, closed } \\
\text { system }\end{array}$ \\
\hline $\begin{array}{l}\text { Early investments can be } \\
\text { earned back on a short term, } \\
\text { and can be properly } \\
\text { exploited and protected } \\
\text { against use by others. }\end{array}$ \\
\hline $\begin{array}{l}\text { Long timelag, closed } \\
\text { system }\end{array}$ \\
\hline $\begin{array}{l}\text { Early investments take long } \\
\text { to be earned back. } \\
\text { Investments can be } \\
\text { protected and closed off to } \\
\text { other players, and may reap } \\
\text { some early }\end{array}$ \\
\hline
\end{tabular}

Short timelag, open system

Early investments can be a earned back on a short term, but can be exploited and used by others as well.

Long timelag, open system Early investments take long to be earned back, and can hardly be protected. Other may use them and can earn benefits without the initial costs. All benefit equally from the early investments by some

Figure 4: The Costs of Investment and the Spread of Benefits

\section{First Steps}

The introduction of e-mobility is an issue connected to a high degree of lock-in and effects related to the burden of the past. Choices early in the process, for example, regarding the leading infrastructure and technical standards, can end up in long term commitment to - on hindsight inferior techniques. Increasingly this involves processes that touch established commercial and political interests, which in turn touch the lives of citizens in action and can generate much media attention. Technology choices are never objective considerations, but are put under pressure by political and strategic concerns. Another feature mentioned earlier is that visible costs always come before expected benefits, and investments are made without guarantees, knowing that benefits can only be distributed after the elaboration of endgame details, which cannot possibly be known at the beginning of the game.

Uncertainty surrounds investment; up until the last moment it can all go wrong. Without intervention chances are limited for the mass introduction of electric cars. The first few thousand cars will roll out of the factories without problems, thanks to government support. What really matters are the steps that take us beyond those first few thousand, or tens of thousands of cars, onwards to mass production and deployment, and the ultimate normality of the electric car.

\subsection{Searching for Smart Strategies}

Turning the process into a success means bringing technical and social assessment together. Announcing intentions or even releasing funds does not mean that the process is well organized. Others have to move as well. The introduction of electric cars requires commitment from the three pillars of government, industry and society. It is far from clear that all the actors involved will find each other easily and simply follow suit. There is no shortage of strategy, in fact there has been a surplus of strategies with individual actors navigating their own courses, all well motivated, all with good intentions. It is a task to bring all of these courses together. And we still have the group of critics, the critical consumers and followers on the lookout for failures. We still have the complex vested interests that will benefit from the failure of the transition to electric vehicles. It is in the opponents' interests to nip the EV transition process in the bud, as quickly and soon as possible; to this end they can exploit all sorts of resources, lobbying politicians, playing the media game and competing for economic opportunities. They can dramatically cut the prices of their carbon-based products, they can produce better, more fuelefficient cars and improve driving performance. 
Settled actors in the automotive industry or the oil industry are not taking direct part in the transition, but they can certainly exert great influence on the process.

\subsection{Smart Strategies and First Steps}

How can we bring together the various stakeholders more effectively to achieve large scale introduction of e-mobility? Discovering the answer to this question is the raison d'etre of this essay. Until now, we have discussed many complicating factors, with the aim of distinguishing the best options for success. The question for this section is how to translate knowledge from various layers of complexity into a smart strategy and, breaking this down into meaningful steps for the introduction of the electric car.

The proposals suggested here, which we will research further and make more concrete, derive from combinations of the dimensions that cause complexity. It is necessary to undertake early action that will have long term effects, either because the action concerned will be significant in the long run, or because it will enable the system to develop significantly. In principle, this would be one government action - or done with a limited number of partners - that mobilizes many other parties into action. The governmentinitiated action should be small, relatively quick and easy to connect. It should have symbolic value, but be more than that. It must deliver a powerful image, but behind the spin must be real content. It should give more than the suggestion of great progress, it should be doing something that really matters.

\subsection{Mobilize Third Parties}

First, it is necessary to get the challengers involved in the process. One of the powerful features of the transition is that it is not primarily embedded in the established actors, but that new and surprising connections can be made. Employing a smart strategy does not imply that government singlehandedly identifies various new actors and brings them together, but it does suggest that government should create the conditions that makes it increasingly likely that these actors will find each other.

The government could encourage banks, supermarkets and department stores to present EV-charging facilities to customers parked on their grounds and offer services around the EVchargers. They could create favorable conditions for leasing companies so that their electric fleets can provide the business market with electric vehicles. Think also of the potential value of highly visible electric vehicles to small businesses, so that the public at large can quickly see the benefits. In Washington, D.C. an EV-based pizza delivery service is clearly demonstrating that electric driving is efficient, reliable and costeffective. The same goes for the electric taxi project in California; from 2011 three locations in San Francisco's Bay Area will be served by 70 etaxis with a battery swap station at each location.

Being a launching customer can help during the introduction: the Californian cities of Santa Monica and Vacaville have made dozens of electric cars visible to the public. Also, parking lots or garages, equipped with solar panels, can be attractive to potential e-car users. A good example is the Sonic Burger parking lot in Vacaville, which includes fast-charging facilities fed by a solar rooftop. For EV drivers, dining and charging go hand-in-hand, and they can see the electricity is generated from sustainable resources. This is how consumers get familiar with the phenomenon of electric driving, without having to delve deeply in the subject. Time and again, the challenge for governments is to allow easy entrance for these types of unexpected actors. This means keeping standards open, awarding innovation grants, or reducing regulatory barriers for a broad spectrum of actors. The dialogue should be open and include not only the auto manufacturers, energy companies and research institutes, but also national business chains (Albert Heijn, Rabobank, New York Pizza), government departments (Veteran Affairs, Labor) and, of course, the car leasing industry.

\subsection{Symbolic Links: fast 'circle corridoring'}

The game is now so large and uncertain that many actors are tending to sit and wait for someone else to do the demolition work. The government is incapable of breaking this impasse by themselves and they shouldn't. But they could make meaningful steps through symbolism and good selection.

From this perspective we think that the idea of circle corridors is interesting. The corridor principle is applied in many US regions, including Baltimore, San Diego and the Bay Area. A series of charging points is constructed, each at a prescribed distance from the next, enabling drivers to recharge EVs along this corridor and travel a decent distance. Stringing charging stations between Haarlem and Amsterdam (about $20 \mathrm{~km}$ ), 
around the Amsterdam Ring or between Amsterdam and Utrecht (about $40 \mathrm{~km}$ ) will create popular pathways. Although the distance traveled on the national road network is relatively limited, in symbolic terms it would count for a lot; for those who have to be in and around Amsterdam the use of EVs is easily justified.

In Japan they have demonstrated that installing rapid charging stations leads to more kilometers driven electrically, not so much because people use these stations to recharge their batteries, but because the stations dramatically reduce the users' range anxiety. People evidently do not use the stations - for the majority of trips there is no actual need - but the fact that the charging stations are there makes the users feel safe enough to drive an EV. The security symbolized by the corridor's chargers allows people to dismiss their fear of electric driving and then, in practice, discover that the predictions are right: they do not actually need fast chargers.

A corridor is not just a network that enables mobility, it is also a marketing network that supports and strengthens city or regional branding. It is an open category: new, small corridors can be constructed, time and again, with five to eight charging points connected to other corridors. Early adopters may play the hub role; a hub is where different networks and corridors meet and where additional services can be provided. Thus, a small step of a placing few charging poles can connect symbolically to far more than that. We call this process 'circle corridoring'.

\subsection{Policymaking and Iconoclasm}

A major problem with the notion of electric cars is that it is usually expressed as a battle between two vehicles. The EV must beat the car which, unfortunately, happens to be one of the most popular consumer products. A powerful industry that uses great marketing and advertising may force a win in this battle of images. Therefore iconoclasm and framing are key elements of any smart government strategy. How to get electric driving to move away from its bold alternative image and become the inevitable, superior solution of the future?

We know from the Apple example that David can beat Goliath: despite holding marginal market share, Apple manages to successfully out run its competitor Microsoft in select domains. Apple not only trumps Microsoft, it has also gained a significant share in the telecom market, between strong players like Nokia and Blackberry. And, up till now Apple has been able to keep Google's Android in check. We can see similar competition between Facebook and Google. A few years ago Google seemed to have won a monopoly on Internet traffic, but Facebook is maneuvering itself as a new giant on the playing field, with powerful technology, but also through selective and above all, smart marketing.

In the case of electric vehicles it could be important to expand the product to other actors than car manufacturers and energy companies. It is still very much about creating new opportunities, but part of the importance of framing also stems from the need to block risks. One thing is certain: the more electric driving becomes a serious alternative, the more the traditional industry will increase resistance. How can electric driving defend itself? How to deal with the first major accident or traffic jam involving an electric car? How to deal with research into the danger of charging stations? How to act if a leaky battery creates victims? How should elected officials address the media if/when a funded initiative goes bankrupt? We urge governments not to start marketing campaigns in favor of electric cars, but to get actively involved in the game of brand imaging electric vehicles in order to tap into new opportunities and access actors who did not know they were connected. It is important to be resilient to inevitable risks. In that sense it is not up to government to start the imaging game; rather, it should enter an existing game and take up its own smart position.

\subsection{Roads That Pay and Vital Coalitions}

According to MIT Professor John Heywood, old cars should be phased out by systematic subsidies in ten years' time. This will serve both the environment and the economy. The banning of leaded gasoline and the imposition of catalytic converters in the 1980s were handled well by the entire automotive industry and consumers. Governments have an explicit role to play here. They can intervene through legislation as well, although we do not necessarily advocate using this tool. Another role for government is that of infrastructure and asset manager, ensuring that EV (road) infrastructure is built, maintained and used. Recently the TNO Institute and the Province of North-Holland in coalition with several companies launched the 'Solaroad'. With this innovation, they want to contribute to sustainable energy-producing infrastructure and perhaps eventually climate- 
neutral mobility. Solaroad combines the functionality of solar cells with transport infrastructure. If all of the $137,000 \mathrm{~km}$ of roads in the Netherlands followed the Solaroad principle, more than enough electricity could be generated for all vehicles to drive on solar energy. It would generate energy, environmental and health benefits and indeed, the road network would pay for itself.

We anticipate that the successful introduction of electric vehicles will need more combinations of instruments like the Solaroad initiative. Government should be encouraging actors, through laws, subsidies, standards and other regulatory interventions, but above all, it should look for promising links and allow new technology to enter government-managed systems. It should always be on the lookout for interventions that provide new platforms for electric vehicle innovations. The government cannot singlehandedly cause the introduction of e-mobility, but it can create platforms and pathways along which stakeholders can move easily and faster to bring the electric car closer to the market.

\section{Conclusion: Smart Strategies for Governance Dilemmas}

Our analysis is intended to clarify why the introduction is at this stage and why, despite early success, it can still get stranded. We have shown that this is not an anomaly, but given the system characteristics, actually a normal development. We have outlined the game playing patterns that have created this situation and that might in future still be typical. If governments do not develop enough clever (smart) strategies, then the currently dominant strategies will linger on: the waiting game, wait and see, free-riding, and half-heartedness will stay on the winning side.

The question is whether existing policies apply sufficient, smart enough strategies. Perhaps the early, quick wins have made them subject to a disadvantage. They obscure the view of the potentially far less prosperous sequel to the now promising-looking first action. Policy is beset with highly ambiguous options. The initial impression we have of the government's own perception is one that smacks of complacency: 'Government should sit back, stop intervening and go with the flow. It's up to the market, to society, to make it happen so let them get on with it.'

Then there is the broad attention given to electric driving, to pilot projects and the first electric cars ordered by individuals. Yes, it is a beginning, and it is going well. That in itself is true, but all this is still no guarantee for success in the long term.

This leads us to the second impression we observe in existing government policy: 'Things must improve, it can all go faster, the scale must be bigger, it must be a mass introduction.' Here policy still faces major obstacles and there is much apprehension about the future. The risk of getting stuck halfway with too much invested to crawl back from and not enough critical mass to persevere becomes even more realistic. In this light, it is important to consider a scaling up strategy, from possibility to reality, from experiment to actual practice, from pilot projects to daily routines. Here, especially, governance will be crucial.

The strategic options that we have proposed are focused on governance and indicate the direction in which scaling up should be contemplated. Though well-considered, our proposals are still rudimentary and will be further supplemented and strengthened, for this essay is certainly not the end of our study. On the contrary, for the next steps, the direction we have chosen is both conceptual and practical development of understanding governance capacity. That is: we are looking at the small steps in the final run up to the 'giant leap'. We are looking for small acts that could have giant repercussions, for government action that creates platforms for others to enter and grow on. A suitable implementation strategy in this respect implies acceptance of the notion of 'patchwork' combinations on all levels: for instance, an automobile could be an electric car with a range extender, and in two-car households, families could take an electric car as their second car. Increasingly, the strength lies in combinations, through stakeholder connections and through the development of new propositions and products.

Uncertainty and confusion as to where the e-car is going is often - even in this essay - regarded as a nuisance. How much easier it would be if the path of e-mobility was clear. This is true, but it would not do justice to the entire process. Indeed, here the very unknown belongs to the promise of electric mobility. What we do not know will surprise us the most and in the most positive manner. We still do not know what electric vehicles may achieve. System innovations often create new innovations. These are partly 
unforeseen, and will have the character of a small catch, but even something small can be of great importance. We do not know what these small things will be, only that we almost certainly will catch them. Policies should therefore be primarily geared to keeping the road to innovation open. Uncertainty should not be limited but actually maximized.

Moving forward to the mass introduction of electric mobility means accepting that we do not know where the first small step will take us. In that sense it is, perhaps, a leap of faith. Through deepening our on-going study we will further explore the parameters so that the giant leap becomes easier to take.

\section{Acknowledgments}

This paper is based on a book entitled "Governing the transition to e-mobility: small steps towards a giant leap", published by Netherlands School of Public Administration, the Hague, in 2010, ISBN: 978-90-75297-15-7, by the same authors and is abbreviated here with permission. Kingsley E. Haynes and Zhenhua Chen did this reduction. An earlier version of this paper was presented at the (57) 2012 Association of American Geographers Annual Meeting in New York in February, 2012.

\section{References}

[1] Boonstra, J. Dynamics of organizational change and learning. Wiley. 2004.

[2] California Air Resources Board.MulfordCarrell Act.www.calepa.gov.ca 1967.

[3] California Air Resources Board.AB32 Global Warming Solutions Act.www.calepa.gov.ca 2005.

[4] Chapple, K., A. Markusen, G. Schrock, D. Yamamoto. Tacit knowledge and the economic geography of context.Association of American Geographers. 2008.

[5] Conservation Leaders Network.Cool Counties Initiatives. National Association of Counties. 2007.

[6] Department of Energy.Innovative Energy Efficiency, Renewable Energy and Advanced Transmission and Distribution. Technologies. 2009.

[7] Devlin. D. Who killed the electric car? Sony Pictures Classics, 2006.

[8] EU Commission.European Energy Policy.www.energy.eu 2007.
[9] EU Commission.20/20 by 2020 Europe's climate change opportunity. 2008.

[10] Freund, E. Living with a BEV: a survey of user experiences. Electric Auto Association. 2008.

[11] Friedman, T.L. Flat, hot and crowded: why we need a green revolution". Farrar, Straus and Giroux. 2008.

[12] Hancock, R and E.D. Carson.The 2009 Index of Silicon Valley.Joint Venture Silicon Valley. 2009.

[13] Hamilton, Madison and Jay.The Federalist Papers.Signet Classic. 1787.

[14] Jacobsen.M.Z. Review of solutions to global warming, air polution, and energy security. EnergyEnvironment.Science. 2009 (2):148-173.

[15] Kingdon. J.W. America the Unusual. Worth Publishers. 1999.

[16] LaMonica, M. Obama lays first piece in energy policy puzzle. CNET News. 2009.

[17] Ministerie van BuitenlandseZaken. De Elektrische Auto in de Verenigde Staten met focus op de staatCalifornië. 2010.

[18] Ministerie van EconomischeZaken.Charging the Electric Vehicle: The Role of EV Charging Infrastructure in the Transportation Transition. 2010.

[19] Ministerie van Financiën. Stimuleringen 2009-2010

alsonderdeelAanvullendBeleidskader 2009. 2015. Kabinetbrief 25 maart 2009.

[20] Nederland Persbureau. Premier Balkenendeomarmt Actieplanelektrischrijden. Persbericht 1 april 2009.

[21] Sandalow, D. Plug-in Electric Vehicles; what role for Washington? Brookings Institute Press. 2008.

[22] Shorto, R. The Island at the center of the world.Vintage Books. 2004.

[23] Steinmetz, J. Plug-in Hybrids: the next automotive revolution. Morgan Stanley. 2008.

[24] StichtingNatuur en Milieu.Milieu Quick-scan van het crisispakket 2009-2010 van het kabinet(2009).

[25] StichtingNatuur en Milieu. Actieplanelektrischrijden: $\quad O p$ wegnaaréénmiljoenelektrische auto's in 2020 ! 2009. 
[26] United Nations. KyotoProtocol.UNFCC Report. 1997.

[27] United States House of Representatives.The American Clean Energy and Security Act (ACES).US Congress Library. 2009.

[28] United States Congress.American Recovery and Reinvestment Act.US Congress Library. 2008.

[29] Waxman, H. H.R. 2454: American Clean Energy and Security Act of 2009. US Congress Library. 2009.

[30] WHO.Bridging the gaps.World Health Organization Reports. 1995.

[31] WRR.InnovatieVernieuwd. Amsterdam University Press. 2006.

\section{Authors}

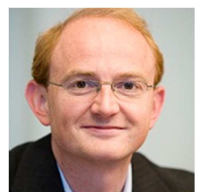

Martijn van der Steen (1977) since 2002 in various positions at the NSOB. He is co-counselor and deputy director of the NSOB and director of the Denktank. In addition to various courses, he is responsible for various research projects and research programs. His research interests include government control in networks, embedding forward-looking concepts in current development policy, the renewal of public administration and the way media and imagery affect processes in public administration.

Dr. Peter van Deventer MPA, is Division Manager Engineering, GIS and Innovation at the Province of North Holland. He has executed extensive research on both policy aspects as well as practical issues

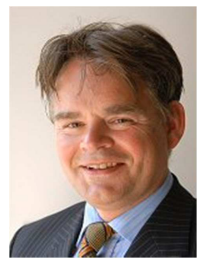
related to large scale introduction of e-mobility. $\mathrm{He}$ is currently responsible for the introduction of emobility in the Amsterdam Metropolitan Region and is a Board Member of the EU INTERREG program on E-mobility in the North Sea Region.

Hans de Bruijn is Professor of Policy Analysis and Management at the Faculty of Technology, Policy and Management at Delft University of Technology. He focuses on management and complex decision-

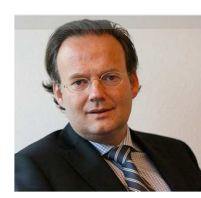

making processes in the public sector and the public/private interface. $\mathrm{He}$ is also associated with the Netherlands School of Public Administration and is Governance Programme Manager at the Netherlands Institute for City Innovation Studies.

Mark van Twist (born 1966) is professor of public administration at Erasmus University Rotterdam. He is also dean and member of the board of the Netherlands School of Public Administration, an interuniversity institute in The Hague, that offers study programs for senior officials in government, and extraordinary member of the board of the Netherlands Court of Audit.

Ernst ten Heuvelhof is scientific director for the NGInfra foundation. $\mathrm{He}$ is professor of Public Administration at the Faculty of Technology, Policy and Management of Delft University of Technology (DUT) and at the Faculty of Social Sciences of Erasmus University Rotterdam. He chairs the department of Management and Governance of the Faculty of Technology, Policy and Management.

Kingsley E. Haynes served as Dean of the School of Public Policy at George Mason University until July 2010. Professor Haynes teaches classes in environmental system

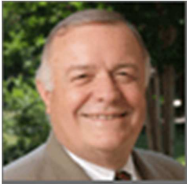
management, policy analysis, urban planning methodology and regional economic development. His recent research activities have focused on minimum information forecasting and intelligent transportation systems.

Zhenhua Chen is a doctoral student and a graduate research assistant in the School of Public Policy at George Mason University. His research interests include regional development and transportation, technology application in transportation policy as well as impact analysis of transportation infrastructure. 